\title{
PD-LI expression in human cancers and its association with clinical outcomes
}

\author{
This article was published in the following Dove Press journal: \\ OncoTargets and Therapy \\ 12 August 2016 \\ Number of times this article has been viewed
}

\section{Xin Wang ${ }^{1,2, *}$ \\ Feifei Teng ${ }^{2,3, *}$ \\ Li Kong ${ }^{2}$ \\ Jinming $\mathrm{Yu}^{2}$}

'School of Medicine and Life Sciences, University of Jinan Shandong Academy of Medical Sciences, ${ }^{2}$ Department of Radiation Oncology, Shandong Cancer Hospital and Institute, ${ }^{3} \mathrm{School}$ of Medicine, Shandong University, Jinan, People's Republic of China

*These authors contributed equally to this work
Correspondence: Jinming Yu Department of Radiation Oncology, Shandong Cancer Hospital and Institute, 440 Jiyan Road, Jinan 250I I7, Shandong, People's Republic of China Tel +8653 I 87984729

Fax +8653187984079

Email sdyujinming@।63.com

\begin{abstract}
PD-L1 is an immunoinhibitory molecule that suppresses the activation of T cells, leading to the progression of tumors. Overexpression of PD-L1 in cancers such as gastric cancer, hepatocellular carcinoma, renal cell carcinoma, esophageal cancer, pancreatic cancer, ovarian cancer, and bladder cancer is associated with poor clinical outcomes. In contrast, PD-L1 expression correlates with better clinical outcomes in breast cancer and merkel cell carcinoma. The prognostic value of PD-L1 expression in lung cancer, colorectal cancer, and melanoma is controversial. Blocking antibodies that target PD-1 and PD-L1 have achieved remarkable response rates in cancer patients who have PD-L1-overexpressing tumors. However, using PD-L1 as an exclusive predictive biomarker for cancer immunotherapy is questionable due to the low accuracy of PD-L1 immunohistochemistry staining. Factors that affect the accuracy of PD-L1 immunohistochemistry staining are as follows. First, antibodies used in different studies have different sensitivity. Second, in different studies, the cut-off value of PD-L1 staining positivity is different. Third, PD-L1 expression in tumors is not uniform, and sampling time and location may affect the results of PD-L1 staining. Therefore, better understanding of tumor microenvironment and use of other biomarkers such as gene marker and combined index are necessary to better identify patients who will benefit from PD-1/PD-L1 checkpoint blockade therapy.
\end{abstract}

Keywords: PD-L1, prognostic value, checkpoint blockade, immunotherapy, clinical outcome

\section{Introduction}

The classic $T$ cell activation is regulated by two signal transduction pathways: one is antigen dependent, and the other is antigen independent. The antigen-independent signaling includes positive and negative second signals. PD-1 and CTLA-4 are two immune-inhibitory checkpoint molecules that suppress $\mathrm{T}$ cell-mediated immune responses, leading to the development of tumors. ${ }^{1}$ Cancer immunoediting is a process that consists of immunosurveillance and tumor progression. ${ }^{2}$ It has three phases: elimination, equilibrium, and escape. In elimination phase, tumor cells are recognized by upregulated tumor antigen expression and killed by different types of immune effector cells. In equilibrium phase, tumor cells change into variants and induce immunosuppression to avoid constant immune pressure, resulting in a state of functional dormancy of the tumor. In escape phase, various immunosuppressive molecules and cytokines are activated by the tumor cells and contribute to tumor outgrowth, causing clinically apparent disease. PD-L1 is a PD-1 ligand that plays an important role in the inhibition of T cell-mediated immune response. Binding of PD-L1 to PD-1 causes the exhaustion of effector T cells and immune escape of tumor cells, leading to poor prognosis. In rare cases, positive PD-L1 expression has been reported to be associated with better clinical outcome. Clinical trials have demonstrated that monoclonal 
antibodies (mAbs) that target PD-L1 or its receptor PD-1 prevent the inhibitory effects of PD-1/PD-L1 pathway and enhance $\mathrm{T}$ cell functions, leading to impressive outcomes in patients with melanoma, renal cell carcinoma ( $\mathrm{RCC}$ ), non-small-cell lung cancer (NSCLC), and bladder cancer. ${ }^{3-5}$ However, the predictive effects of PD-L1 in response to PD-1/PD-L1 antibodies in some tumors are not conclusive, and the indication of PD-L1 expression in tumors remains controversial and needs to be understood profoundly. This review focuses on PD-L1 expression and its association with clinical outcomes in different cancers and factors affecting the accuracy of prediction of PD-L1. We also discuss the value of PD-L1 in predicting the clinical efficacy of PD-1/ PD-L1 checkpoint blockades in cancer patients.

\section{Expression and biological function of PD-LI}

PD-L1 is mainly expressed on the surface of tumor cells and antigen-presenting cells in various solid malignancies such as squamous cell carcinoma of the head and neck, melanoma, and carcinomas of the brain, thyroid, thymus, esophagus, lung, breast, gastrointestinal tract, colorectum, liver, pancreas, kidney, adrenal cortex, bladder, urothelium, ovary, and skin. ${ }^{6-12}$ In tumor microenvironment, PD-L1 expression on tumor cells and other tumor-promoting cells is caused by two mechanisms, constitutive mechanism and induced mechanism, both of which depend on two binding sites of IRF-1. ${ }^{13}$ For example, in BRAFV600-mutated melanoma, PD-L1 expression is a result of cancer cells' adaptive response to immune attack evoked by cytokines, or a constitutive expression which is a result of oncogenic processes. ${ }^{14}$ PD-L1 is rarely expressed on normal tissues but inducibly expressed on tumor site, which makes PD-L1 pathway uniquely different from other coinhibitory pathways, ${ }^{15}$ indicating that the selective expression of PD-L1 may have some association with clinical outcomes of the cancer patients and can be a selective target for antitumor therapy.

PD-1 (CD279), a PD-L1 receptor, is expressed on $\mathrm{CD}^{-} \mathrm{CD}^{-}$thymocytes and $\mathrm{CD} 4^{+} \mathrm{CD} 8^{+} \mathrm{T}$ cells during thymic development and is selectively expressed on $\mathrm{CD}^{+}$and $\mathrm{CD}^{+} \mathrm{T}$ cells, monocytes, natural killer $\mathrm{T}$ cells, B cells, and dendritic cells upon induction by TCR and cytokine arousal. ${ }^{16,17}$ In chronically infected mice model, high expression of PD-1 on T cells leads to T cell exhaustion and makes the exhausted $\mathrm{CD}^{+} \mathrm{T}$ cells lose effector function of secreting cytokines such as IL-2, IFN- $\gamma$, and TNF- $\alpha .{ }^{18}$ Binding of PD-L1 to PD-1 leads to the formation of PD-1/TCR inhibitory microcluster that recruits SHP1/2 molecule and dephosphorylates multiple members of TCR signaling pathway, leading to the shut-off of T cell activation through induction of apoptosis, reduction of proliferation, and inhibition of cytokine secretion (Figure 1). However, whether all

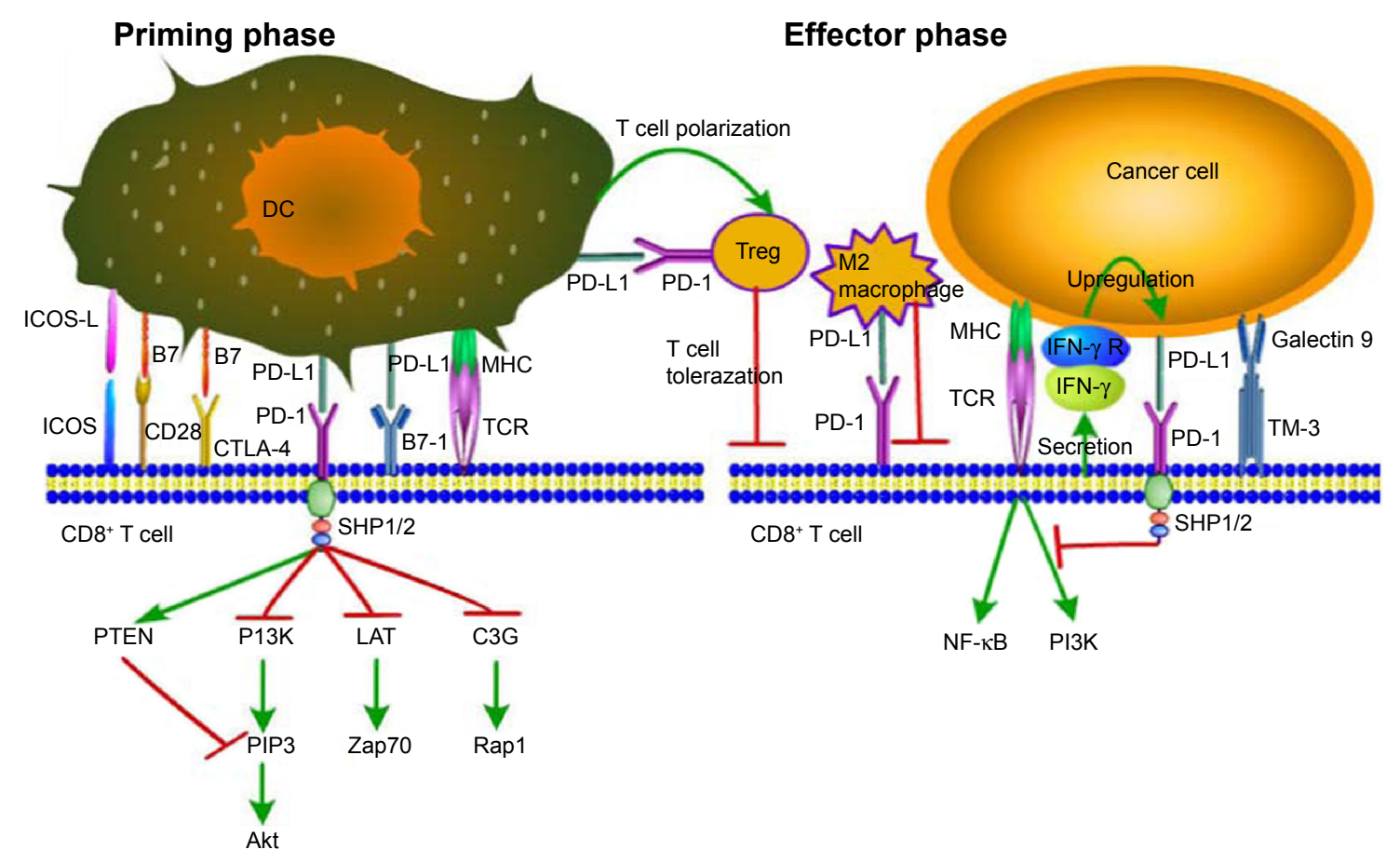

Figure I PD-I/PD-LI signaling: decreased CD8 ${ }^{+} \mathrm{T}$ cell proliferation, survival, and cytokine production.

Abbreviations: DC, dendritic cell; Treg, regulatory T cell; ICOS, inducible costimulator; ICOS-L, inducible costimulator-ligand; CD28, cluster of differentiation 28; CTLA-4, cytotoxic T lymphocyte-associated antigen-4; PD-LI, programmed death-ligand I; PD-I, programmed death-I; MHC, major histocompatibility complex; TCR, T cell receptor; IFN- $\gamma$, interferon- $\gamma$; IFN- $\gamma$ R, interferon- $\gamma$ Receptor. 
kinds of cancers utilize the same action mechanism of PD-L1 signaling, that is, whether different prognosis of different cancers is caused by different PD-L1 mechanisms, remains inconclusive and needs to be further explored.

PD-1/PD-L1 pathway plays a prominent role in immune regulation by delivering inhibitory signals to maintain the balance in $\mathrm{T}$ cell activation, tolerance, and immune-mediated tissue damage. It exerts significant inhibitory functions in persistent antigenic stimulation environment such as exposure to self-antigen, chronic viral infection, and tumor. ${ }^{19-21}$ PD-L1 can also serve as a receptor transmitting antiapoptotic signal to tumor cells to protect them from apoptosis. Moreover, Shi et $\mathrm{al}^{22}$ have demonstrated that PD-L1 may have oncogenic function during colon cancer carcinogenesis. PD-L1 not only inhibits $\mathrm{T}$ cell proliferation and cytokine production but also enhances $\mathrm{T}$ cell activation. ${ }^{23}$ The explanation of this contradictory phenomenon is unknown.

In normal tissues, PD-1 signaling in T cells regulates immune responses to decrease damage to adjacent tissue, and counteracts the development of autoimmunity by promoting tolerance to self-antigens. $\mathrm{PD}-\mathrm{L} 1$ receptor is also expressed on the surface of $\mathrm{CD}^{+}{ }^{+}$Foxp $3^{+}$regulatory $\mathrm{T}$ cells (Tregs), a subset of $\mathrm{CD}^{+} \mathrm{T}$ cells that play a critical role in maintaining immune tolerance and weakening immune responses, to promote the development, maintenance, and immunosuppressive function of Tregs through inhibiting mTOR and AKT phosphorylation. ${ }^{24}$

\section{Prognostic value of PD-LI in malignancies}

Table 1 summarizes the studies on the prognostic value of PD-L1 in different malignancies. Some malignancies such as hepatocellular carcinoma, pancreatic cancer (PC), gastric cancer, RCC, esophageal cancer (EC), and ovarian cancer can generate an immunosuppressive tumor microenvironment by expressing high-aggregate PD-L1 to avoid cytolysis by activated $T$ cells. It may explain why overexpression of high-aggregate PD-L1 in tumors leads to poor prognosis in cancer patients. Interestingly, several long-term follow-up investigations have found an inverse correlation between PD-L1 expression on tumor cells and poor prognosis of patients. Additionally, in lung cancer, colorectal cancer (CRC), and melanoma, PD-L1 expression has both positive and negative prediction values. In thymoma and thymic carcinoma, squamous cell carcinoma of the lung, and cervical cancer, PD-L1 expression alone is not of prognostic value but is of significant prediction value when combined with other indicators such as $\mathrm{CD}^{+} /$ Foxp $3^{+} \mathrm{T}$ cell ratio.

\section{Lung cancer}

Two studies demonstrated that PD-L1 expression on tumor cells is correlated with poor prognosis in NSCLC patients. Both the studies detected PD-L1 expression both on membrane and in cytoplasm of tumor cells, but the cut-off value for PD-L1 immunohistochemistry (IHC) positivity was not mentioned. ${ }^{25,26}$ Azuma et $\mathrm{al}^{26}$ revealed that expression of highaggregate PD-L1 on tumor cells is associated with EGFR gene mutations. Mu et $\mathrm{a}^{25}$ evaluated the intensity of PD-L1 expression in 109 NSCLC specimens. By IHC analysis, strong association was found between PD-L1 expression and shorter survival time in adenocarcinoma patients.

Two other studies showed a positive correlation between better clinical outcomes and PD-L1 expression. Velcheti et $\mathrm{al}^{27}$ assessed the predictive value of PD-L1 expression in two cohorts with 204 and 340 specimens, respectively. Tumor PD-L1 expression was found in 36\% (Greek) and 25\% (Yale) of the cases. Patients with PD-L1 expression above the detection threshold showed significantly better outcome. In 2014, Yang et $\mathrm{al}^{28}$ reported that patients with positive PD-L1 expression on tumor cell membrane had better relapse-free survival. Importantly, Boland et $\mathrm{al}^{29}$ showed that PD-L1 is not of independent prognostic value in squamous cell carcinoma of the lung. Based on the above studies, we conclude that PD-L1 has controversial predictive function in lung cancer.

\section{Gastric cancer}

Three articles reported the negative prediction value of PD-L1 in gastric cancer patients. Hou et $\mathrm{al}^{30}$ found that 70 of 111 patients had positive PD-L1 expression either on membrane or in the cytoplasm of tumor cells, and there was a positive correlation between the expression of PD-L1 and poor prognosis. The cut-off value was $10 \%$ in their study. The study by Hou et al also demonstrated that the combination of increased number of Foxp $3^{+}$Tregs and increased expression of PD-L1 is an even stronger predictor of lower overall survival (OS) rate and worse prognosis as compared to each individual factor alone. The other two studies did not mention the cut-off values of PD-L1 IHC staining; both of them showed that PD-L1 is of independent prognostic value. ${ }^{31,32} \mathrm{Wu}$ et $\mathrm{al}^{31}$ examined 43 of 102 specimens and found that PD-L1 expression is mainly in the cytoplasm of tumor cells. Qing et $\mathrm{al}^{32}$ showed that 54 of 107 cases had positive PD-L1 expression. Both studies demonstrated that PD-L1 expression is significantly associated with invasion and lymph node metastasis, which are poor prognostic factors of tumors. In conclusion, gastric cancer patients with positive PD-L1 expression have a significantly poorer prognosis than PD-L1-negative patients. 
Table I Prognostic value of PD-LI in different malignancies

\begin{tabular}{lll}
\hline Disease & $\begin{array}{l}\text { Detection method; PD-LI } \\
\text { detection antibody }\end{array}$ & Location of PD-LI expression \\
& curface expression \\
cut-off for & positivity \\
\hline
\end{tabular}

Thymoma and IOI and $38 \quad$ Paraffin IHC; anti-PD-LI (clone EIL3N) thymic carcinoma

Adrenocortical 28 carcinoma

8

\author{
Paraffin IHC; monoclonal anti-PD-LI
} antibody (405.9AII)

Frozen IHC; anti-PD-LI (5HI)

Head and neck
squamous cancer

Malignant brain 83

tumors

Glioma

54

10

Lung cancer

109

164

Paraffin IHC; anti-PD-LI (Lifespan

Biosciences, Seattle, WA, USA);

flow cytometry

204 and 340 Paraffin IHC; anti-PD-LI (clone 5HI)

163

Paraffin IHC; anti-PD-LI (Proteintech

Group Inc., Chicago, IL, USA)

214 Paraffin IHC; anti-PD-LI (clone 5HI, laboratory developed)

120 and 10 Paraffin IHC; anti-PD-LI

52 Frozen IHC; anti-B7-HI (MIHI)

Gastric cancer III Paraffin IHC; anti-Foxp3 $3^{+}$(polyclonal antibody, Sigma-Aldrich Co., St Louis, MO, USA) and anti-PD-LI (polyclonal antibody; Abcam, Cambridge, UK)

I02 Paraffin IHC; anti-B7-HI (2HII)

107 Paraffin IHC; anti-PD-LI (polyclonal antibody)
$70 \%$ of thymic carcinoma (type $C$ ) and $23 \%$

$1 \%$ of thymoma (types $A, A B$, and $B$ ) samples were positive for PD-LI

PD-LI expression was detected both on $5 \%$ tumor cell membrane and in TIMCs

Eleven of 24 specimens had intracytoplasmic staining, eleven of 24 tumors had membrane reactivity, and ten of 24 had both $61 \%$ of brain tumors (but no WHO grade I NA tumors) expressed PD-LI

NA

NA

Strong PD-LI expression was detected in all NA ten glioma samples examined

PD-LI expression on membrane and in NA cytoplasm of tumors with cluster and scattered patterns

PD-LI was detected on membrane or in the cytoplasm (or both) of tumor cells and stromal lymphocytes in the surgically resected tumor specimens

NA

NA

PD-LI expressed on membrane of tumor cells

PD-LI predominately expressed on membrane 5\% and minimally expressed in cytoplasm

NA

NA

PD-LI expression in cytoplasm or on NA membrane or both, in focal or scattered patterns in all 52 specimens of NSCLC

70 of I I I cases demonstrated PD-LI expression on the membrane or in the cytoplasm

PD-LI was expressed mainly in the cytoplasm; NA some nuclear membrane localization was also present

54 of 107 cases had positive PD-LI expression NA 


\section{TIL or other immunocytes associated with PD-LI expression}

Other clinicopathological factors associated with PD-LI expression
Clinical outcomes

Study
NA

NA

NA

NA

NA

NA

CDI $\alpha^{+}$TIDC was increased in PD-LI+ portions of tumor and had higher expression of PD-LI than CD83 ${ }^{+}$DCs NA

PD-LI protein and mRNA expression was consistently associated with increased local lymphocytic infiltrate The degree of $\mathrm{T}$ lymphocytes infiltration was slightly higher in PD-LI-positive tumors than in PD-LI-negative ones

PD-LI expression had no significant correlation with infiltrating lymphocytes

NA

In a subset of five patients, the amount of $T$ lymphocytes infiltration was significantly reduced in PD-LIexpressing tumor regions Significant correlation was found between the infiltration of Foxp $3^{+}$ Tregs and the expression of PD-LI on the tumor cells and TILs NA

NA
Higher PD-LI expression was more likely to exhibit male, more advanced pathological features, including WHO classification type and Masaoka-Koga stage

PD-LI positivity on either tumor cell membrane or in TIMCs was not significantly associated with higher stage at diagnosis, higher tumor grade, and excessive hormone secretion

16 of 24 specimens had PD-LI staining

NA

PD-LI expression was closely correlated with the grade of the tumor

NA

PD-LI+ cells in adenocarcinoma were more than in squamous cell carcinoma

PD-LI expression is significantly higher in females, never smokers, those with adenocarcinoma histology, and those with EGFR mutations

In Greek cohort, PD-LI expression had association with tumor stage and inflammation, while in Yale cohort, with histology and inflammation Higher PD-LI expression was correlated with higher grade differentiation and vascular invasion

NA

PD-LI overexpression was related to poor tumor cell differentiation and advanced TNM stage

No correlation was observed between PD-LI expression and clinicopathologica characteristics

High-level Foxp3+ Tregs and PD-LI expression led to lymph node metastasis and an advanced clinicopathological stage

42.2\% of gastric carcinoma tissues were PD-LI+. PD-LI correlated with tumor size, invasion, and lymph node metastasis Positive PD-LI expressions were significantly associated with depth of invasion, lymph node metastasis, pathological type, higher $T$ stage, and higher differentiation
PD-LI positivity was not a significant negative factor of OS

PD-LI expressed on both tumor Fay et $\mathrm{al}^{9}$ cell membrane and in TIMCs with no relationship with 5-year OS

NA

Strome et $\mathrm{al}^{10}$

NA

Jacobs et $\mathrm{al}^{11}$

NA

Wilmotte et al $^{12}$

NA

Wintterle et $\mathrm{al}^{82}$

PD-LI positivity correlated with survival shorter than 3 years after lobectomy

PD-LI overexpression was associated with a significantly shorter OS for NSCLC patients and had independent negative prognostic value

Patients with PD-LI expression above the detection threshold showed statistically significant better outcome

Positive PD-LI expression had better RFS. Advanced-stage and positive VPSI were significant risk factors for poor prognosis of OS

PD-LI was not of independent prognostic value in squamous cell carcinoma of the lung

PD-LI- NSCLC patients had longer overall 5-year survival than PD-LI+ patients. PD-LI status had independent prognostic value of NSCLC

No correlation between PD-LI expression and patient survival

Enhanced expression of Foxp $3^{+}$Tregs and

Hou et $\mathrm{al}^{30}$ PD-LI exhibited a lower OS rate and a worse prognosis

PD-LI expression was an independent prognostic factor and correlated with poorer survival

PD-LI-positive gastric cancers were significantly associated with a poor prognosis
Mu et $\mathrm{al}^{25}$

Azuma et $\mathrm{al}^{26}$

Velcheti et $\mathrm{a}^{27}$

Yang et $\mathrm{al}^{28}$

Boland et $\mathrm{al}^{29}$

Chen et al $^{62}$

Konishi et $\mathrm{al}^{8}$

Wu et $\mathrm{al}^{31}$

Qing et $\mathrm{al}^{32}$

(Continued) 
Table I (Continued)

\begin{tabular}{|c|c|c|c|c|}
\hline Disease & $\mathbf{N}$ & $\begin{array}{l}\text { Detection method; PD-LI } \\
\text { detection antibody }\end{array}$ & Location of PD-LI expression & $\begin{array}{l}\text { PD-LI tumor } \\
\text { surface expression } \\
\text { cut-off for } \\
\text { positivity }\end{array}$ \\
\hline & 205 & Paraffin IHC, FACS; anti-PD-LI & $\begin{array}{l}88 \text { of } 205 \text { gastric carcinoma tissues were } \\
\text { PD-LI positive and were mainly distributed } \\
\text { in cytoplasm and on membrane of the tumor } \\
\text { cells }\end{array}$ & NA \\
\hline \multirow[t]{4}{*}{ CRC } & 143 & $\begin{array}{l}\text { Paraffin IHC; anti-PD-LI } \\
\text { (ab588I0; Abcam) }\end{array}$ & $\begin{array}{l}64 \text { patients }(44.8 \%) \text { showed positive PD-LI } \\
\text { expression in the cytoplasm and on the } \\
\text { membrane }\end{array}$ & NA \\
\hline & $1,49 \mid$ & $\begin{array}{l}\text { Paraffin IHC; anti-PD-LI mAb (clone 27A2; } \\
\text { MBL International Corporation, } \\
\text { Woburn, MA, USA) }\end{array}$ & $\begin{array}{l}\text { Strong PD-LI expression was observed } \\
\text { in } 37 \% \text { of MMR-proficient and in } 29 \% \\
\text { of MMR-deficient CRCs }\end{array}$ & NA \\
\hline & 185 & $\begin{array}{l}\text { Paraffin IHC; polyclonal anti-PD-LI } \\
\text { antibody }\end{array}$ & $\begin{array}{l}\text { PD-LI was expressed in cytoplasm and } \\
\text { on membrane of the tumor cells }\end{array}$ & NA \\
\hline & 56 & Paraffin IHC; anti-PD-LI & Cytoplasm and/or membrane & NA \\
\hline \multirow[t]{2}{*}{$\begin{array}{l}\text { Esophageal } \\
\text { cancer }\end{array}$} & 41 & $\begin{array}{l}\text { Frozen IHC, mRNA analysis; anti-PD-LI } \\
\text { (MIHI, mouse immunoglobulin GI) }\end{array}$ & $\begin{array}{l}\text { I8 of } 4 \text { I positive cases expressed PD-LI or } \\
\text { PD-L2 on the plasma membrane and in the } \\
\text { cytoplasm of cancer cells }\end{array}$ & $10 \%$ \\
\hline & 99 & $\begin{array}{l}\text { Paraffin IHC, FACS; anti-PD-LI } \\
\text { (NBPI-03220; Novus International, } \\
\text { St Louis, MO, USA) }\end{array}$ & $\begin{array}{l}82 \text { of } 99 \text { patients demonstrated positive } \\
\text { membranous/cytoplasmic PD-LI staining, } \\
\text { and } 79 \text { of } 99 \text { patients demonstrated positive } \\
\text { nuclear PD-LI staining }\end{array}$ & NA \\
\hline \multirow[t]{4}{*}{ Pancreatic cancer } & 51 & $\begin{array}{l}\text { Frozen IHC, FACS; anti-human PD-LI } \\
\text { (MIHI, mouse immunoglobulin GI) }\end{array}$ & $\begin{array}{l}\text { PD-LI was expressed mainly on the plasma } \\
\text { membrane and in the cytoplasm of cancer cells }\end{array}$ & $10 \%$ \\
\hline & 81 & Paraffin IHC; anti-PD-LI (MIHI; eBioscience) & PD-LI was located primarily in the cytoplasm & $5 \%$ \\
\hline & 40 and 10 & $\begin{array}{l}\text { Paraffin IHC; anti-PD-LI (monoclonal } \\
\text { number: } 2 \mathrm{HII} \text { ) }\end{array}$ & $\begin{array}{l}\text { PD-LI was intensely expressed in pancreatic } \\
\text { carcinoma tissues, and weakly expressed in } \\
\text { cytoplasm of islet cells }\end{array}$ & $10 \%$ \\
\hline & 40 and 8 & $\begin{array}{l}\text { Paraffin IHC; anti-PD-LI (clone I30002; R\&D } \\
\text { Systems, Inc., Minneapolis, MN, USA) }\end{array}$ & $\begin{array}{l}\text { PD-LI was located primarily in the cytoplasm } \\
\text { of the tumor cells }\end{array}$ & NA \\
\hline $\begin{array}{l}\text { Malignant pleural } \\
\text { mesothelioma }\end{array}$ & 106 & Paraffin IHC; anti-PD-LI (clone 5HI-A3) & Cytoplasmic and/or membranous & $5 \%$ \\
\hline $\begin{array}{l}\text { Merkel cell } \\
\text { carcinoma }\end{array}$ & 67 & Paraffin IHC; anti-PD-LI (5HI) & $\begin{array}{l}\text { PD-LI expressed on membrane of tumor } \\
\text { cells and TILs }\end{array}$ & $5 \%$ \\
\hline MEL & 59 & $\begin{array}{l}\text { Paraffin IHC; anti-B7-HI (clone 27A2, } \\
\text { MBL International Corporation) }\end{array}$ & PD-LI expressed in tumor cell cytoplasm & NA \\
\hline
\end{tabular}




\section{TIL or other immunocytes associated with PD-LI expression}

IFN- $\gamma$ and $\mathrm{CD}^{+} T$ cells infiltration was found in carcinoma tissues

NA

In MMR-proficient CRC, correlation between strong PD-LI expression and infiltration by $\mathrm{CD} 8^{+}$lymphocytes was found

$\mathrm{CD}^{+} \mathrm{T}$ cells in $\mathrm{PD}-\mathrm{LI}^{+}$specimens were significantly lower than that in $\mathrm{PD}-\mathrm{LI}^{-}$patients but no difference of $\mathrm{CD}^{+} \mathrm{T}$ cells

A significant correlation between Tregs infiltration and PD-LI expression was found

No significant correlation was found between PD-LI expression and tumor-infiltrating $T$ lymphocytes. PD-L2 expression was inversely correlated with tumor-infiltrating $\mathrm{CD}^{+} \mathrm{T}$ cells

PD-LI expression was found significantly associated with the infiltrating density of Foxp $3^{+}$Tregs

PD-LI expression was inversely correlated with tumor-infiltrating T lymphocytes, particularly CD8 ${ }^{+}$ $T$ cells

PD-LI resulted in the inhibition of $\mathrm{CD}^{+}$and $\mathrm{CD} 8^{+} \mathrm{T}$-cell activation and promotion of tumor growth NA

NA

NA

A high density of $C D 8^{+}$cells was associated with PD-LI expression by tumor cells and by TILs NA

\section{Other clinicopathological factors associated with PD-LI expression}

Study

Jiang et $\mathrm{al}^{83}$
High PD-LI expression was correlated with
age, carcinoma location, and differentiation

PD-LI was significantly associated with cell differentiation status and TNM stage

PD-LI expression in MMR-proficient CRC was significantly associated with early $\mathrm{T}$ stage, absence of lymph node metastases, lower tumor grade, and absence of vascular invasion Positive tumor PD-LI expression was associated with lymph node metastasis

PD-LI expression was positively correlated to the infiltration depth, lymph node metastasis, and advanced Duke's stage PD-LI-positive status was associated with advanced stage of cancer with positive lymph node metastasis and distant metastasis

Membranous or cytoplasmic PD-LI expression was correlated with tumor invasion depth, and not correlated with other clinicopathological factors. Nuclear PD-LI expression was significantly correlated with tumor invasion depth There was no significant correlation between tumor PD-LI status and clinical indicators including tumor status, nodal status, metastatic status, and pathologic stage PD-LI significantly correlated with the pathological grade and TNM stage

PD-LI expression was significantly associated with the staging of tumor and preoperative serum CAI 99 level PD-LI expression was significantly associated with poor tumor differentiation and advanced tumor stage PD-LI positivity was less likely to undergo therapeutic surgery and more likely to be a sarcomatoid mesothelioma subtype

Expression of PD-LI by either tumor cells or infiltrating immune cells did not correlate with patient's sex, age, or pathologic stage Higher PD-LI expression was found in high tumor stage, primary tumors with lymphonodus metastasis, and metastatic lymphonodus
Positive PD-LI expression showed a trend of shorter survival time; PD-LI expression is an independent predictor of colorectal carcinoma prognosis

PD-LI expression was paradoxically associated with improved survival in MMR-proficient CRC

High PD-LI was closely correlated with poor prognosis

NA

PD-LI and PD-L2 expression led to significantly poorer prognosis

Positive PD-LI expression on membrane or in cytoplasm led to poorer OS but positive nuclear PD-LI staining did not

$\mathrm{PD}-\mathrm{LI}^{+}$patients had a significantly poorer prognosis than the PD-LI ${ }^{-}$patients. PD-LI was an independent prognostic factor

PD-LI-positive status was a prognostic indicator of poor disease-specific survival

PD-LI was an independent factor for poor prognosis

PD-LI overexpression in human pancreatic carcinoma tissues might have associations with tumor progression and invasiveness PD-LI was expressed in a substantial proportion of malignant pleural mesotheliomas and was associated with poor survival

Tumor cell PD-LI expression, but not TIL PD-LI expression, was associated with improved OS

PD-LI expression was an independent predictor of poor OS and DFS
Zhao et $\mathrm{a}^{85}$

Shi et $\mathrm{a}^{22}$

Droeser et $\mathrm{a}^{33}$

Liang et $\mathrm{al}^{35}$

Ohashi et $\mathrm{al}^{36}$

Chen et $\mathrm{al}^{37}$

Nomi et al ${ }^{8}$

Wang et $\mathrm{a}^{38}$

Chen et $\mathrm{a}^{39}$

Geng et $\mathrm{al}^{40}$

Mansfield et a ${ }^{51}$

Lipson et a ${ }^{61}$

Hino et $\mathrm{a}^{63}$ 
Table I (Continued)

\begin{tabular}{|c|c|c|c|c|}
\hline Disease & $\mathbf{N}$ & $\begin{array}{l}\text { Detection method; PD-LI } \\
\text { detection antibody }\end{array}$ & Location of PD-LI expression & $\begin{array}{l}\text { PD-LI tumor } \\
\text { surface expression } \\
\text { cut-off for } \\
\text { positivity }\end{array}$ \\
\hline & 150 & Paraffin IHC; anti-PD-LI mAb (5HI) & $\begin{array}{l}\text { Membranous PD-LI expression by } \\
\text { melanocytes within the tumors and in the TILs }\end{array}$ & $5 \%$ \\
\hline Cervical cancer & 115 & Paraffin IHC; anti-B7-HI (5HI) & $\begin{array}{l}\text { PD-LI expressed on tumor cell membrane } \\
\text { and throughout tumor bed }\end{array}$ & NA \\
\hline Bladder cancer & 50 & $\begin{array}{l}\text { Paraffin IHC; anti-human PD-LI polyclonal } \\
\text { antibody (Santa Cruz Biotechnology Inc., } \\
\text { Dallas, TX, USA) }\end{array}$ & $\begin{array}{l}\text { PD-LI expressed in the cytoplasm or on the } \\
\text { membrane of tumor cells }\end{array}$ & $10 \%$ \\
\hline $\begin{array}{l}\text { Differentiated } \\
\text { thyroid } \\
\text { carcinoma }\end{array}$ & 407 & $\begin{array}{l}\text { Paraffin IHC; anti-PD-LI polyclonal antibody } \\
\text { (prediluted; ab82059; Abcam) }\end{array}$ & $\begin{array}{l}\text { PD-LI expression was detected in the } \\
\text { cytoplasm of tumor cells }\end{array}$ & NA \\
\hline Sarcoma & 50 & Paraffin IHC; anti-PD-LI & PD-LI expressed on plasma membrane & $1 \%$ \\
\hline $\begin{array}{l}\text { Oropharyngeal } \\
\text { squamous cell } \\
\text { carcinoma }\end{array}$ & 181 & Paraffin IHC; anti-PD-LI (clone A3) & $\begin{array}{l}84 \text { of } I 8 I \text { positive cases demonstrated both } \\
\text { membranous and cytoplasmic staining }\end{array}$ & $5 \%$ \\
\hline ICC & 31 & $\begin{array}{l}\text { Paraffin IHC, functional assays; anti-PD-LI } \\
\text { (Abcam) }\end{array}$ & $\begin{array}{l}\text { Varying degrees of PD-LI expression on } \\
\text { plasma membrane and in cytoplasm of cancer } \\
\text { cells were found in all } 3 \mathrm{I} \mathrm{ICC} \mathrm{cases}\end{array}$ & NA \\
\hline $\begin{array}{l}\text { Multiple } \\
\text { myeloma }\end{array}$ & 82 & $\begin{array}{l}\text { FACS, Western blot analysis, mRNA analysis; } \\
\text { anti-PD-LI (MIHI for FACS, N20 for } \\
\text { Western blot analysis) }\end{array}$ & $\begin{array}{l}\text { PD-LI was detected in most multiple myeloma } \\
\text { plasma cell samples }\end{array}$ & NA \\
\hline Leukemia & 30 & $\begin{array}{l}\text { FACS, functional assays, frozen IHC; } \\
\text { anti-PD-LI }(5 \mathrm{HI})\end{array}$ & $\begin{array}{l}\text { I7 of } 30 \text { samples of human leukemia cells } \\
\text { were } \mathrm{B}_{-}-\mathrm{HI}^{+}\end{array}$ & NA \\
\hline & 60 & Real-time PCR, IHC; anti-PD-LI & $\begin{array}{l}\text { PD-LI expressed mainly on the plasma } \\
\text { membrane of cancer cells }\end{array}$ & 2.0 for real-time PCR \\
\hline \multirow[t]{2}{*}{$\mathrm{HCC}$} & $|4|$ & $\begin{array}{l}\text { Paraffin IHC; anti-human PD-LI (BioLegend, } \\
\text { San Diego, CA, USA); FACS with } \\
\text { PE-conjugated anti-PD-LI }\end{array}$ & NA & NA \\
\hline & 240 and 125 & $\begin{array}{l}\text { Paraffin IHC; anti-PD-LI (eBioscience); } \\
\text { Western blot analysis }\end{array}$ & $\begin{array}{l}\text { PD-LI was shown on the cell membrane, in } \\
\text { the cytoplasm, or both in a focal or scattered } \\
\text { pattern }\end{array}$ & NA \\
\hline
\end{tabular}
pattern 


\section{TIL or other immunocytes associated with PD-LI expression}

\section{Other clinicopathological factors associated with PD-LI expression}

Clinical outcomes

Study
Almost all PD-LI+ tumors were associated with TILs, whereas only $28 \%$ of PD-LI- tumors were associated with TIL

PD-LI expression was associated with higher Foxp $3^{+} \mathrm{T}$ cells infiltration but not with $\mathrm{CD} 8^{+} \mathrm{T}$ cells

NA

Elevated levels of PD-LI protein were associated with the presence of $\mathrm{CD}^{+}, \mathrm{CD}^{+}, \mathrm{CD}^{2} \mathrm{O}^{+}$, and $\mathrm{Foxp} 3^{+}$ lymphocytes

Positive tumor PD-LI expression and lymphocytic PD-LI expression were associated with high-density CD8 ${ }^{+}$cells

NA

Tumor-infiltrating CD8 $8^{+}$lymphocytes were significantly lower in III-IV and poorly differentiated tumors. A significant inverse correlation between tumor-related PD-LI expression and CD8 ${ }^{+}$TILs count was found

NA

NA

NA

NA

Significant positive correlation between PD-LI expression and Foxp $3^{+}$Treg cell infiltration was found
PD-LI expression was associated with the superficial spreading and nodular MEL subtypes and not with MEL stage

In patients with $\mathrm{PD}-\mathrm{LI}^{+}$or $\mathrm{PD}-\mathrm{LI}^{-}$tumors, more than half of the infiltrating CD8 $T$ cells and half of the Foxp $3^{+} T$ cells expressed PD-I

PD-LI expression was strongly associated with the pathological grade, clinical stage, and recurrence of bladder cancer

Elevated levels of PD-LI protein were associated with tumor-associated macrophages, and the presence of myeloidderived suppressor cells. Higher PD-LI mRNA level was associated with stages II-IV and higher age PD-LI expression had no association with various clinicopathological factors

PD-LI expression was associated with worse $\mathrm{N}$ stage and distant metastasis

Tumor-related PD-LI expression was significantly correlated with a poorer histological differentiation and a more advanced PTNM stage

NA

NA

PD-LI was significantly higher in the relapse M5 patients and those with complicated pulmonary infections

Circulating PD-LI expression was closely correlated with intratumoral PD-LI expression. PD-I/PD-LI expression was associated with tumor size and blood vessel invasion

PD-LI expression was an independent prognostic factor for tumor vascular invasion, encapsulation, and TNM stage
PD-LI expression was associated with

Taube et $\mathbf{a}^{164}$ improved survival in metastatic MEL but not primary invasive MEL

PD-LI expression had no independent prognosis value; OS of patients with PD-LI+ tumors and a low $\mathrm{CD}^{+} / \mathrm{Foxp}^{+} \mathrm{T}$ cell ratio was better than in patients with a PD-LItumor and a low $\mathrm{CD}^{+} / \mathrm{Foxp}^{+} \mathrm{T}$-cell ratio PD-LI-positive group had a lower survival rate than negative group. PD-LI was of independent prognostic value in bladder cancer

PD-LI positivity had no prognostic value

There was no association between OS and PD-LI expression in tumor or immune infiltrates

No correlation was found between PD-LI expression and patient survival

NA

NA

NA

PD-LI status was defined to be an independent prognostic factor; PD-LIpositive patients had a poorer prognosis than the negative patients

Patients with higher expression of circulating PD-LI had a significantly shorter OS and tumor-free survival than those with lower expression

Patients with PD-LI+ tumors had poorer DFS and OS than patients with PD-LI tumors; PD-LI status was an independent prognostic factor for DFS, and PD-LI+ patients were nearly two times more likely to suffer from relapse after resection than $\mathrm{PD}^{-\mathrm{LI}^{-}}$patients
Cunha et a $l^{69}$

Ye et $\mathrm{a}^{72}$

Liu et $\mathrm{al}^{73}$

Salih et $\mathrm{al}^{74}$

Chen et $\mathrm{al}^{89}$

Karim et al ${ }^{65}$

Wang et $a^{68}$

D'Angelo et $\mathrm{al}^{70}$

Ukpo et $\mathrm{al}^{71}$

Zeng et $\mathrm{a}^{57}$

Gao et $\mathrm{al}^{75}$

(Continued) 
Table I (Continued)

\begin{tabular}{|c|c|c|c|c|}
\hline Disease & $\mathbf{N}$ & $\begin{array}{l}\text { Detection method; PD-LI } \\
\text { detection antibody }\end{array}$ & Location of PD-LI expression & $\begin{array}{l}\text { PD-LI tumor } \\
\text { surface expression } \\
\text { cut-off for } \\
\text { positivity }\end{array}$ \\
\hline & 56 & $\begin{array}{l}\text { Paraffin IHC, FACS; anti-PD-LI (BioLegend); } \\
\text { FACS with PE-conjugated PD-LI } \\
\text { (eBioscience) }\end{array}$ & Cytoplasmic and membranous & NA \\
\hline & 26 & Frozen IHC; anti-PD-LI (MIHI; eBioscience) & $\begin{array}{l}\text { PD-LI was expressed on the membrane } \\
\text { of tumor cells; focal or scattered }\end{array}$ & NA \\
\hline \multirow[t]{3}{*}{$\mathrm{RCC}$} & 429 & Paraffin IHC; anti-PD-LI (5HI) & $\begin{array}{l}\text { PD-LI expression on both tumor cells } \\
\text { and lymphocytes }\end{array}$ & $10 \%$ \\
\hline & 306 & Paraffin IHC; anti-PD-LI (5HI) & NA & $5 \%$ \\
\hline & 196 & Paraffin IHC; anti-PD-LI (clone 5HI) & $\begin{array}{l}\text { PD-LI expression on both tumor cells } \\
\text { and lymphocytes }\end{array}$ & $10 \%$ \\
\hline \multirow[t]{5}{*}{ UCB } & 65 & Frozen IHC; anti-PD-LI (MIHI) & $\begin{array}{l}\text { PD-LI present on plasma membrane and/or in } \\
\text { cytoplasm of urothelial cancer cells in a focal } \\
\text { pattern }\end{array}$ & $12.2 \%$ \\
\hline & 160 & Paraffin IHC; anti-PD-LI (405.9AII) & $\begin{array}{l}\text { PD-LI expressed on tumor cell membrane } \\
\text { and TIMCs }\end{array}$ & $5 \%$ \\
\hline & 410 & Paraffin IHC; anti-PD-LI & $\begin{array}{l}\text { PD-LI expression was detected on cell } \\
\text { membrane and occasionally in cytoplasm }\end{array}$ & $5 \%$ \\
\hline & 280 & Paraffin IHC; anti-PD-LI (clone 5HI) & PD-LI expressed on plasma membrane & $1 \%$ \\
\hline & 302 & Paraffin IHC; anti-PD-LI & $\begin{array}{l}\text { PD-LI expression primarily on the cell } \\
\text { membrane; cytoplasmic staining was } \\
\text { occasionally detected }\end{array}$ & $5 \%$ \\
\hline \multirow[t]{3}{*}{ Ovarian cancer } & 70 & Paraffin IHC; anti-PD-LI (clone 27A2) & NA & NA \\
\hline & 70 & $\begin{array}{l}\text { Paraffin IHC; anti-PD-LI (27A2; } \\
\text { MBL International Corporation) }\end{array}$ & NA & NA \\
\hline & NA & $\begin{array}{l}\text { FACS, functional assays; anti-PD-LI } \\
\text { (BD Pharmingen Inc.) for FACS, } 5 \mathrm{HI} \\
\text { for functional assays }\end{array}$ & $\begin{array}{l}\text { PD-LI present on nearly all myeloid DCs from } \\
\text { tumor ascites and from tumor-draining lymph } \\
\text { nodes }\end{array}$ & NA \\
\hline Breast cancer & 636 & RNAscope assay & $\begin{array}{l}\text { PD-LI mRNA expressed in nearly } 60 \% \text { of } \\
\text { breast tumor }\end{array}$ & NA \\
\hline
\end{tabular}




\section{TIL or other immunocytes associated with PD-LI expression} Other clinicopathological factors
associated with PD-LI expression
Clinical outcomes

Study
$\mathrm{CD}^{+} \mathrm{T}$ cells were mainly distributed NA

around the PD-LI+ ${ }^{+}$portion of

tumor nest

PD- $\mathrm{I}^{+} \mathrm{T}$ cells accumulated within tumors and in peritumoral areas

NA

NA

NA

In 13 examined cases, most TILs expressed high levels of PD-I

NA

Tumor expression of PD-LI was significantly associated with TIL expression of PD-I

NA

NA

PD-LI expression inversely correlated with intraepithelial CD8 ${ }^{+}$ TIL count

Negative correlation between CD8 ${ }^{+}$ cell infiltration and PD-LI tumor expression

NA

Higher PD-LI mRNA expression was significantly associated with increased TILs. The presence of elevated TILs was significantly associated with ER-negative status
24 of 26 HCC specimens expressed PD-LI; PD-LI expression was associated with hepatitis $B$ virus infection and with earlier tumor stage

This combined PD-LI expression was associated with regional lymph node involvement, distant metastases, nuclear grade, and histologic tumor necrosis, all of which have been shown to portend a poor prognosis

PD-LI+ tumors were associated with TNM stage III or IV, tumor size of $\geq 5 \mathrm{~cm}$, nuclear grade 3 or 4 , and coagulative tumor necrosis

High PD-LI expression was associated with regional lymph node involvement, distant metastases, advanced nuclear grade, and tumor necrosis

PD-LI expression correlated with WHO grade and primary tumor classification

PD-LI expression had no association with various clinicopathological factors

PD-LI expression was significantly associated with advanced tumor stage and a greater degree of TILs

PD-LI expression was associated with high-grade tumors and tumor infiltration by mononuclear cells

PD-LI was not associated with various clinicopathological factors

PD-LI had no statistically significant correlation with various clinicopathological factors

NA

NA

PD-LI mRNA expression was significantly associated with the presence of elevated TILs but not other clinicopathological factors
NA

Shi et a ${ }^{76}$

NA

Wang et $\mathrm{al}^{84}$

Positive PD-LI expression was close to three times more likely to die from RCC compared with negative PD-LI expression patients. The combination of increased tumor cell PD-LI and lymphocyte PD-LI is an even stronger predictor of patient outcome

Patients with PD-LI+ tumors had increased risk of death from RCC and overall

Thompson et al ${ }^{66}$ mortality and decreased 5-year survival

Patients with high PD-LI expression was

Thompson significantly more likely to die of RCC

et $\mathrm{al}^{77}$

Increased PD-LI expression

Nakanishi et al

was associated with poor survival and increased possibility of postresection recurrence

Positive PD-LI expression in TIMCs

associated with longer survival in metastatic tumors

PD-LI expression independently predicted increased all-cause mortality after

cystectomy for patients with organ-confined tumors

Increasing levels of PD-LI expression

Inman et $\mathrm{al}^{79}$

correlate with increased local

aggressiveness of this cancer

In patients with organ-confined UCB, PD-LI Xylinas et a ${ }^{80}$

expression was associated with an increased risk of overall mortality

High expression of PD-LI had worse 5-year survival rate and $O S$ rate

Hamanishi et al ${ }^{59}$

High PD-LI expression had independent negative prognostic value

Hamanishi et $\mathrm{al}^{67}$

NA

Curiel et $\mathrm{a}^{86}$

PD-LI mRNA expression was associated with longer recurrence-free survival
Schalper et $\mathbf{a}^{60}$ 
Table I (Continued)

\begin{tabular}{|c|c|c|c|c|}
\hline Disease & $\mathbf{N}$ & $\begin{array}{l}\text { Detection method; PD-LI } \\
\text { detection antibody }\end{array}$ & Location of PD-LI expression & $\begin{array}{l}\text { PD-LI tumor } \\
\text { surface expression } \\
\text { cut-off for } \\
\text { positivity }\end{array}$ \\
\hline & 44 & $\begin{array}{l}\text { FACS, frozen IHC; anti-PD-LI } \\
\text { (MIHI; eBioscience) }\end{array}$ & $\begin{array}{l}\text { PD-LI expressed both on membrane } \\
\text { and in cytoplasm }\end{array}$ & NA \\
\hline
\end{tabular}

WT

|9|

139

Nasopharyngeal

carcinoma
Paraffin IHC; anti-PD-LI

Paraffin IHC; anti-PD-LI
Eleven tumors expressed PD-LI. Tumors with $\mathrm{AH}$ were more likely to express PD-LI compared to FH tumors

PD-LI expression was detected in 132 patients, which was located on tumor tissue
NA

NA

\begin{abstract}
Abbreviations: TIL, tumor-infiltrating lymphocyte; IHC, immunohistochemistry; NA, not available; WHO, World Health Organization; TIMCs, tumor-infiltrating mononuclear cells; FACS, fluorescence-activated cell sorting; DCs, dendritic cells; NSCLC, non-small-cell lung cancer; RFS, relapse-free survival; VPSI, visceral pleural surface invasion; OS, overall survival; TNM, tumor-node-metastasis; CRC, colorectal cancer; mAb, monoclonal antibody; MMR, mismatch repair; Tregs, regulatory T cells; DFS, diseasefree survival; MEL, melanoma; ICC, intrahepatic cholangiocarcinoma; PTNM, pathological TNM; PCR, polymerase chain reaction; PE, phycoerythrin; HCC, hepatocellular carcinoma; RCC, renal cell carcinoma; UCB, urothelial cancer of the bladder; WT, Wilms' tumor; AH, anaplastic histology; FH, favorable histology.
\end{abstract}

\section{Colorectal cancer}

PD-L1 expression in CRC has not been fully addressed so far. Nevertheless, a strong correlation between PD-L1 expression on tumor cells and discrepant clinical outcomes has been observed. In CRC gene spectrum, DNA mismatch repair (MMR) status, known as MMR proficient and MMR deficient, has clinical significance in predicting the prognosis upon PD-L1 expression on tumor cells. ${ }^{33}$ MMR-proficient tumors are characterized by concurrent expression of MLH1, MSH2, and MSH6, whereas MMR-deficient tumors are characterized by lacking of expression of at least one of these markers. ${ }^{34}$ Droeser et $\mathrm{al}^{33}$ analyzed PD-L1 expression in two subtypes of CRCs, including 1,197 MMR-proficient and 223 MMR-deficient CRCs. They detected strong PD-L1 expression in $37 \%$ of MMR-proficient and in $29 \%$ of MMR-deficient CRCs. PD-L1 expression is associated with improved survival in MMR-proficient CRCs, which might be due to concomitant increase of $\mathrm{CD} 8^{+} \mathrm{T}$ cells infiltration.

In contrast, another two studies showed that positive PD-L1 expression in tumor is an independent predictor of poor CRC prognosis. ${ }^{22,35}$ Thus, the predictive value of PD-L1 expression on tumor cells is controversial in CRC patients.

\section{Esophageal cancer}

Positive correlation between PD-L1 expression and poor prognosis in EC was reported by two studies. ${ }^{36,37}$
Ohigashi et a $\mathrm{l}^{36}$ selected $10 \%$ as cut-off value and illustrated that 18 of 41 positive cases express PD-L1 or PD-L2 on the plasma membrane and in the cytoplasm of cancer cells. Although no significant correlation was found between PD-L1 expression and number of tumor-infiltrating $\mathrm{T}$ lymphocytes, PD-L2 expression was found to be inversely correlated with number of tumor-infiltrating $\mathrm{CD} 8^{+} \mathrm{T}$ cells. They also found that the expression of either PD-L1 or PD-L2 has significant prognostic value and the combination of expression of PD-L1 and PD-L2 leads to significantly poorer prognosis in postoperative EC patients. Their result further demonstrates that the roles of PD-L1 and PD-L2 in tumor immune escape differ depending on tumor types.

In a study carried out by Chen et al, ${ }^{37} \mathrm{PD}-\mathrm{L} 1$ expression was found to be significantly associated with the infiltrating density of Foxp $3^{+}$Tregs, but the cut-off value of PD-L1 expression was not mentioned. They concluded that membrane PD-L1, but not nuclear PD-L1, expression is associated with poor OS in EC patients.

\section{Pancreatic cancer}

Four studies focused on PC have achieved similar results showing that PD-L1 expression in human pancreatic carcinoma tissues is associated with poor prognosis. Nomi et a ${ }^{8}$ recruited 51 PC patients and selected $10 \%$ as cut-off value of PD-L1 expression on tumor cells. They observed that 


\begin{tabular}{|c|c|c|c|}
\hline $\begin{array}{l}\text { TIL or other immunocytes } \\
\text { associated with PD-LI } \\
\text { expression }\end{array}$ & $\begin{array}{l}\text { Other clinicopathological factors } \\
\text { associated with PD-LI expression }\end{array}$ & Clinical outcomes & Study \\
\hline NA & $\begin{array}{l}\text { Intratumoral PD-LI expression was } \\
\text { associated with histologic stage III-negative, } \\
\text { estrogen receptor-negative, and } \\
\text { progesterone receptor-negative patients. } \\
\text { TIL PD-LI was associated with large tumor } \\
\text { size, histologic grade 3, positivity of Her2/ } \\
\text { neu status, and increased tumor lymphocyte } \\
\text { infiltration }\end{array}$ & NA & Ghebeh et $\mathrm{al}^{87}$ \\
\hline NA & $\begin{array}{l}\text { PD-LI expression within WT correlates } \\
\text { with biological aggressiveness, including } \\
\text { stage and histology }\end{array}$ & $\begin{array}{l}\text { Tumor PD-LI expression was significantly } \\
\text { predictive of cancer recurrence }\end{array}$ & Routh et a ${ }^{88}$ \\
\hline $\begin{array}{l}\text { PD-I and PD-LI coexpression } \\
\text { leading to } T \text { cell exhaustion }\end{array}$ & $\begin{array}{l}\text { PD-LI expression had no significant } \\
\text { correlation with clinicopathological factors } \\
\text { such as age, tumor stage, lymph node } \\
\text { metastasis, and clinical TNM staging }\end{array}$ & $\begin{array}{l}\text { High expression of PD-LI in tumor } \\
\text { tissue significantly correlated with a poor } \\
\text { prognosis of DFS }\end{array}$ & Zhang et $\mathrm{al}^{90}$ \\
\hline
\end{tabular}

PD-L1 expression is inversely correlated with number of tumor-infiltrating $\mathrm{T}$ lymphocytes, particularly $\mathrm{CD}^{+} \mathrm{T}$ cells, which might be a reason for the poor prognosis of PD-L1 ${ }^{+}$ patients. Similarly, Wang et $\mathrm{al}^{38}$ also found that PD-L1 inhibits activation of $\mathrm{CD}^{+}$and $\mathrm{CD}^{+} \mathrm{T}$ cells in tumor microenvironment in spite of selecting $5 \%$ as cut-off value for PD-L1 expression. Inhibition of effector T cell function could promote tumor growth, which may explain the poor prognosis of PD-L1-positive patients. Chen et $\mathrm{al}^{39}$ confirmed that PD-L1 is an independent factor of poor prognosis and its expression is significantly associated with the stage of the tumor and preoperative serum CA199 level. Geng et $\mathrm{al}^{40}$ found that PD-L1 overexpression in human pancreatic carcinoma tissues might have associations with tumor progression and invasiveness, which has significant correlation with poor OS. Collectively, PD-L1 expression is correlated with poor clinical outcomes in PC.

\section{PD-LI expression as a predictive biomarker in cancer therapy}

PD-1/PD-L1 pathway is a significant mechanism of immune suppression within tumor microenvironment. mAbs targeting PD-1 or PD-L1 could block the PD-1/PD-L1 pathway and enhance T cell functions. Thus, mAbs to PD-1 and PD-L1, as well as PD-L2 fusion protein, are widely tested in different clinical trials. Pidilizumab, lambrolizumab, nivolumab, and
AMP-224 are mAbs targeting PD-1, whereas BMS-936559, MEDI4736, MPDL3280A, and MSB0010718C are mAbs to PD-L1. ${ }^{41}$ These mAbs were used in the treatment of malignancies including melanoma, NSCLC, RCC, bladder cancer, $\mathrm{CRC}$, and gastric cancer. The overall response rates achieved was $16 \%-100 \%$. $^{3,42}$ Consequently, an effective predictive biomarker is needed to select "real" patients who will benefit from cancer immunotherapy while avoiding unnecessary toxicity. Tumor PD-L1 expression as a predictive biomarker has been evaluated in many clinical trials. For example, CheckMate $037^{43}$ study confirmed that nivolumab has better clinical efficacy than chemotherapy. Weber et $\mathrm{al}^{43}$ randomly allocated 272 patients to nivolumab and 133 to investigator's choice of chemotherapy. The pretreatment PD-L1-positive number was 134 (49\%) and $67(50 \%)$, respectively. Confirmed objective response rate (ORR) was found in $31.7 \%$ of the first 120 patients in the nivolumab group versus $10.6 \%$ of 47 patients in the group that received investigator's choice of chemotherapy. Importantly, the complete response rates were $3.3 \%$ versus $0 \%$. A Phase I expansion study was implemented by Powles et $\mathrm{al}^{44}$ to investigate the responsiveness of PD-L1-positive and PDL1-negative patients to MPDL3280A. The PD-L1-positive patients achieved 43\% (95\% confidence interval [CI]: 26\%-63\%) response rate, whereas the PD-L1-negative patients achieved a response rate of $11 \%(95 \% \mathrm{CI}: 4 \%-26 \%)$, 
demonstrating the therapeutic activity of MPDL3280A in PD-L1-positive patients with urothelial bladder cancer. Both the studies demonstrated that tumor PD-L1 expression is an effective predictor of the outcomes of cancer immunotherapy. Nevertheless, the predictive value of PD-L1 is not consistent in cancer patients. For instance, in Phase III trials of CheckMate $017^{45}$ and CheckMate $057,{ }^{46}$ the clinical efficacy of nivolumab versus docetaxel in previously treated advanced or metastatic squamous NSCLC and non-squamous NSCLC was evaluated, respectively. The nivolumab group achieved longer OS (9.2 versus 6.0 months $[P=0.00025]$ and 12.2 versus 9.4 months $[P=0.0015]$, respectively) and higher ORR (20\% versus $9 \%[P=0.0083]$ and $19 \%$ versus $12 \%[P=0.0246]$, respectively) than patients treated with docetaxel in two studies, but the better progression-free survival was only achieved in squamous NSCLC (CheckMate 017). ${ }^{45}$ Importantly, the beneficial effect of nivolumab in squamous NSCLC is irrelevant to PD-L1 expression, whereas in nonsquamous NSCLC, PD-L1 expression is predictive of the benefit of nivolumab. ${ }^{46}$ Moreover, some PD-L1-negative patients also respond to PD-1/PD-L1 blockade therapy. Therefore, using tumor PD-L1 expression as exclusionary predictive biomarker for the outcome of PD-1/PD-L1 blockade therapy has its limitations. ${ }^{47}$

mAbs targeting PD-1/PD-L1 pathway have achieved impressive response rates in patients with melanoma, NSCLC, RCC, and bladder cancer, and the value of PD-L1 as a predictive biomarker for the outcomes of $\mathrm{mAb}$ therapy has been demonstrated in many studies. ${ }^{3-5}$ Other predictive biomarkers for the prognosis of PD-L1 mAb immunotherapy in cancers have also been investigated. In 2015, ASCO, a Phase II study, confirmed the first gene predictive biomarker-MMR deficiency could effectively predict PD-1 blockade efficacy. In 41 patients with or without MMR deficiency, the ORR was $40 \%$ for MMR-deficient CRC patients and $0 \%$ for MMR-proficient CRC patients. The progression-free survival rate was $78 \%$ for MMR-deficient CRC patients and $11 \%$ for MMR-proficient CRC patients. ${ }^{48}$ More biomarkers should be investigated to facilitate the accurate selection of patients who can benefit from PD-1/ PD-L1 blockade therapy.

\section{Explanations of PD-LI prognostic and predictive value}

IHC-based detection of PD-L1 has limitations because of its subjectivity in determining a clear definition of "positive" tumor PD-L1 staining. ${ }^{49,50}$ Antibodies used in different studies include M1H1, 5H1, 5H1-A3, 2H11, 27A2, 405.9A11, and
E1L3N. 6,10,12,31,33,51,52 Different PD-L1 antibody clones can be a reason for lower PD-L1 expression in some studies. In addition to technical issues with IHC, temporal and spatial factors should also be considered when assessing PD-L1 in cancers. Specimens that were obtained when PD-L1 overexpression in tumor microenvironment has already taken place or patients' specimens that missed the pertinent tumor-immune interface may lead to a bias in PD-L1's predictive value in cancers. ${ }^{53}$ Furthermore, interferon- $\gamma$ secreted by tumor-infiltrating lymphocytes may cause upregulation of PD-L1 on tumor cells, leading to the induction of T cell apoptosis via PD-L1 and PD-1 interaction. Collectively, the prognostic value of PD-L1 IHC relies on the time of biopsy that is associated with the development of the nidus and is related to previous therapies including chemotherapy or radiotherapy. Deng et $\mathrm{al}^{54}$ demonstrated that tumor PD-L1 expression is upregulated after irradiation in mouse models. Therefore, single-time point evaluation of PD-L1 expression may not reflect the real condition, and multiple sites sampling is necessary for the determination of PD-L1 expression.

Spatial impact is another consideration when assessing PD-L1 expression in cancers. PD-L1 expression status may differ in primary lesions versus metastatic lesions due to tumor heterogeneity. PD-L1 expression has two patterns, focal expression and diffuse expression. ${ }^{55}$ Even from the same sample, impertinent biopsy may result in a bias due to the focal nature of PD-L1 expression in many tumors. Assessment of PD-L1 expression in tumor or peritumor is also a question. Thus, selection of the optimum site for biopsy for assessing PD-L1 expression status remains challenging and needs further studies.

Difficulties in comparing different, sometimes even contrary, results also arise from the following considerations: available data are retrospective, patients have different clinical characteristics, tumor samples from different tumor types or different locations of the same tumor are heterogeneous, and PD-L1 positivity is defined by membrane and/or cytoplasmic PD-L1 immunostaining. Several studies have demonstrated that only cell membrane-expressed PD-L1 has biological significance. ${ }^{56}$ Therefore, it is more reasonable to analyze correlations between membrane PD-L1 protein, rather than intracellular PD-L1 protein or mRNA, and clinical outcomes.

MMR, the first gene predictive biomarker that bridges the immunotherapy and genomics, effectively predicts PD-1 blockade efficacy in various cancers. It is necessary to develop more genetic methods to improve the effective prediction of cancer immunotherapy, and select "real" patients who are most likely to benefit from the immunotherapy. As the candidates of predictive marker, $\mathrm{CD}^{+} \mathrm{T}$ lymphocytes and 
IFN- $\gamma$ may be evaluated in consideration of their importance in tumor microenvironment.

\section{Conclusion}

Studies have demonstrated that binding of tumor PD-L1 to its receptor PD-1 on $\mathrm{T}$ cell surface inhibits infiltrating $\mathrm{T}$ cell activation and subsequent lysis of tumor cells. PD-L1 expression in tumors strongly correlates with poor prognosis in gastric cancer, hepatocellular carcinoma, RCC, EC, PC, and ovarian cancer. ${ }^{30,37,39,57-59}$ However, opposite results have been observed in breast cancer and merkel cell carcinoma, where tumor PD-L1 expression correlates with a better prognosis. ${ }^{60,61}$ In lung cancer, CRC, and melanoma, PD-L1 expression has both positive and negative prediction value. .33, $35-64^{3}$ The controversy in PD-L1's diagnostic and predictive value may be due to the following reasons. First, IHC-based detection of PD-L1 has technical issues, and the results may not accurately reflect the real PD-L1 expression status. Second, detection of PD-L1 expression in tumors is affected by temporal and spatial factors, leading to erroneous interpretation of the results. In addition, PD-L1 expression heterogeneity should also be taken into consideration. All these factors illustrate the limitation of using tumor PD-L1 expression as an exclusive biomarker for cancer immunotherapy. However, we cannot ignore the value of PD-L1 expression in selecting patients who will benefit from immunotherapy. Many clinical trials have demonstrated that immunotherapy significantly improves progression-free survival in patients. Remarkably, the grade 3 or 4 adverse events were evidently decreased compared to chemotherapy. ${ }^{45,91-93}$

Other effective biomarkers such as gene marker or combined indexes and improved understanding of tumor microenvironment are needed to accurately determine which patients will benefit from PD-1/PD-L1 pathway blockade therapy and to avoid the unnecessary autoimmune side effects from overtreatment.

\section{Disclosure}

The authors report no conflicts of interest in this work.

\section{References}

1. Ichikawa M, Chen L. Role of B7-H1 and B7-H4 molecules in downregulating effector phase of T-cell immunity: novel cancer escaping mechanisms. Front Biosci. 2005;10:2856-2860.

2. Mittal D, Gubin MM, Schreiber RD, Smyth MJ. New insights into cancer immunoediting and its three component phases - elimination, equilibrium and escape. Curr Opin Immunol. 2014;27:16-25.

3. Ohaegbulam KC, Assal A, Lazar-Molnar E, Yao Y, Zang X. Human cancer immunotherapy with antibodies to the PD-1 and PD-L1 pathway. Trends Mol Med. 2015;21(1):24-33.
4. Alexandrov LB, Serena NZ, Wedge DC, et al. Signatures of mutational processes in human cancer. Nature. 2013;500:415-421.

5. Allison JP. Immune checkpoint blockade in cancer therapy: the 2015 Lasker-DeBakey Clinical Medical Research Award. JAMA. 2015; 314(11):1113-1114.

6. Katsuya Y, Fujita Y, Horinouchi H, Ohe Y, Watanabe S, Tsuta K. Immunohistochemical status of PD-L1 in thymoma and thymic carcinoma. Lung Cancer. 2015;88(2):154-159.

7. Nakanishi J, Wada Y, Matsumoto K, Azuma M, Kikuchi K, Ueda S. Overexpression of B7-H1 (PD-L1) significantly associates with tumor grade and postoperative prognosis in human urothelial cancers. Cancer Immunol Immunother. 2007;56(8):1173-1182.

8. Nomi T, Sho M, Akahori T, et al. Clinical significance and therapeutic potential of the programmed death-1 ligand/programmed death-1 pathway in human pancreatic cancer. Clin Cancer Res. 2007;13(7): 2151-2157.

9. Fay AP, Signoretti S, Callea M, et al. Programmed death ligand-1 expression in adrenocortical carcinoma: an exploratory biomarker study. J Immunother Cancer. 2015;3:3.

10. Strome SE, Dong H, Tamura H, et al. B7-H1 blockade augments adoptive T-cell immunotherapy for squamous cell carcinoma. Cancer Res. 2003; 63(19):6501-6505.

11. Jacobs JF, Idema AJ, Bol KF, et al. Regulatory T cells and the PD-L1/ $\mathrm{PD}-1$ pathway mediate immune suppression in malignant human brain tumors. Neuro Oncol. 2009;11(4):394-402.

12. Wilmotte R, Burkhardt K, Kindler V, et al. B7-homolog 1 expression by human glioma: a new mechanism of immune evasion. Neuroreport. 2005;16(10):1081-1085.

13. Lee SJ, Jang BC, Lee SW, et al. Interferon regulatory factor-1 is prerequisite to the constitutive expression and IFN-gamma-induced upregulation of B7-H1 (CD274). FEBS Lett. 2006;580(3):755-762.

14. Khalili JS, Liu S, Rodríguez-Cruz TG, et al. Oncogenic BRAF(V600E) promotes stromal cell-mediated immunosuppression via induction of interleukin-1 in melanoma. Clin Cancer Res. 2012;18(19): 5329-5340.

15. Dong H, Strome SE, Salomao DR, et al. Tumor-associated B7-H1 promotes T-cell apoptosis: a potential mechanism of immune evasion. Nat Med. 2002;8(8):793-800.

16. Keir ME, Butte MJ, Freeman GJ, Sharpe AH. PD-1 and its ligands in tolerance and immunity. Annu Rev Immunol. 2008;26:677-704.

17. Ishida Y, Agata Y, Shibahara K, Honjo T. Induced expression of PD-1, a novel member of the immunoglobulin gene superfamily, upon programmed cell death. EMBO J. 1992;11(11):3887-3895.

18. Barber DL, Wherry EJ, Masopust D, et al. Restoring function in exhausted CD8 T cells during chronic viral infection. Nature. 2006;439: 682-687.

19. Sharpe AH, Wherry EJ, Ahmed R, Freeman GJ. The function of programmed cell death 1 and its ligands in regulating autoimmunity and infection. Nat Immunol. 2007;8(3):239-245.

20. Okazaki T, Honjo T. PD-1 and PD-1 ligands: from discovery to clinical application. Int Immunol. 2007;19(7):813-824.

21. Nurieva RI, Liu X, Dong C. Yin-Yang of costimulation: crucial controls of immune tolerance and function. Immunol Rev. 2009;229(1):88-100.

22. Shi SJ, Wang LJ, Wang GD, et al. B7-H1 expression is associated with poor prognosis in colorectal carcinoma and regulates the proliferation and invasion of HCT116 colorectal cancer cells. PLoS One. 2013; 8(10):e76012.

23. Yamazaki T, Akiba H, Koyanagi A, Azuma M, Yagita H, Okumura K. Blockade of B7-H1 on macrophages suppresses CD4+ T cell proliferation by augmenting IFN-gamma-induced nitric oxide production. J Immunol. 2005;175(3):1586-1592.

24. Francisco LM, Sage PT, Sharpe AH. The PD-1 pathway in tolerance and autoimmunity. Immunol Rev. 2010;236:219-242.

25. Mu CY, Huang JA, Chen Y, Chen C, Zhang XG. High expression of PD-L1 in lung cancer may contribute to poor prognosis and tumor cells immune escape through suppressing tumor infiltrating dendritic cells maturation. Med Oncol. 2011;28(3):682-688. 
26. Azuma K, Ota K, Kawahara A, et al. Association of PD-L1 overexpression with activating EGFR mutations in surgically resected nonsmallcell lung cancer. Ann Oncol. 2014;25(10):1935-1940.

27. Velcheti V, Schalper KA, Carvajal DE, et al. Programmed death ligand-1 expression in non-small cell lung cancer. Lab Invest. 2014;94: 107-116.

28. Yang CY, Lin MW, Chang YL, Wu CT, Yang PC. Programmed cell death-ligand 1 expression in surgically resected stage I pulmonary adenocarcinoma and its correlation with driver mutations and clinical outcomes. Eur J Cancer. 2014;50(7):1361-1369.

29. Boland JM, Kwon ED, Harrington SM, et al. Tumor B7-H1 and B7-H3 expression in squamous cell carcinoma of the lung. Clin Lung Cancer. 2013;14(2):157-163.

30. Hou J, Yu Z, Xiang R, et al. Correlation between infiltration of FOXP3+ regulatory $\mathrm{T}$ cells and expression of $\mathrm{B} 7-\mathrm{H} 1$ in the tumor tissues of gastric cancer. Exp Mol Pathol. 2014;96(3):284-291.

31. Wu C, Zhu Y, Jiang J, Zhao J, Zhang XG, Xu LN. Immunohistochemical localization of programmed death-1 ligand-1 (PD-L1) in gastric carcinoma and its clinical significance. Acta Histochem. 2006; 108(1):19-24.

32. Qing Y, Li Q, Ren T, et al. Upregulation of PD-L1 and APE1 is associated with tumorigenesis and poor prognosis of gastric cancer. Drug Des Dev Ther. 2015;9:901-909.

33. Droeser RA, Hirt C, Viehl CT, et al. Clinical impact of programmed cell death ligand 1 expression in colorectal cancer. Eur J Cancer. 2013; 49(9):2233-2242.

34. Lugli A, Zlobec I, Baker K, et al. Prognostic significance of mucins in colorectal cancer with different DNA mismatch-repair status. J Clin Pathol. 2007;60(5):534-539.

35. Liang $\mathrm{M}, \mathrm{Li} \mathrm{J}, \mathrm{Wang} \mathrm{D}$, et al. T-cell infiltration and expressions of $\mathrm{T}$ lymphocyte co-inhibitory B7-H1 and B7-H4 molecules among colorectal cancer patients in northeast China's Heilongjiang province. Tumour Biol. 2014;35(1):55-60.

36. Ohigashi Y, Sho M, Yamada Y, et al. Clinical significance of programmed death-1 ligand-1 and programmed death-1 ligand-2 expression in human esophageal cancer. Clin Cancer Res. 2005;11(8):2947-2953.

37. Chen L, Deng H, Lu M, et al. B7-H1 expression associates with tumor invasion and predicts patient's survival in human esophageal cancer. Int J Clin Exp Pathol. 2014;7(9):6015-6023.

38. Wang L, Ma Q, Chen X, Guo K, Li J, Zhang M. Clinical significance of B7-H1 and B7-1 expressions in pancreatic carcinoma. World J Surg. 2010;34(5):1059-1065.

39. Chen XL, Yuan SX, Chen C, Mao YX, Xu G, Wang XY. [Expression of B7-H1 protein in human pancreatic carcinoma tissues and its clinical significance]. Ai Zheng. 2009;28(12):1328-1332. Chinese.

40. Geng L, Huang D, Liu J, et al. B7-H1 up-regulated expression in human pancreatic carcinoma tissue associates with tumor progression. J Cancer Res Clin Oncol. 2008;134(9):1021-1027.

41. Sznol M, Chen L. Antagonist antibodies to PD-1 and B7-H1 (PD-L1) in the treatment of advanced human cancer. Clin Cancer Res. 2013;19(5): 1021-1034.

42. Spigel DR, Gettinger SN, Horn L, et al. Clinical activity, safety, and biomarkers of MPDL3280A, an engineered PD-L1 antibody in patients with locally advanced or metastatic non-small cell lung cancer (NSCLC). J Clin Oncol. 2013;31(Suppl):abstr 8008.

43. Weber JS, D’Angelo SP, David M, et al. Nivolumab versus chemotherapy in patients with advanced melanoma who progressed after anti-CTLA-4 treatment (CheckMate 037): a randomised, controlled, open-label, phase 3 trial. Lancet Oncol. 2015;16:375-384.

44. Powles T, Eder JP, Fine GD, et al. MPDL3280A (anti-PD-L1) treatment leads to clinical activity in metastatic bladder cancer. Nature. 2014; 515:558-562.

45. Brahmer J, Reckamp KL, Baas P, et al. Nivolumab versus docetaxel in advanced squamous-cell non-small-cell lung cancer. $N$ Engl J Med. 2015;373:123-135.

46. Borghaei H, Paz-Ares L, Horn L, et al. Nivolumab versus docetaxel in advanced nonsquamous non-small-cell lung cancer. $N$ Engl J Med. 2015;373:1627-1639.
47. Wolchok JD, Harriet K, Callahan MK, et al. Nivolumab plus ipilimumab in advanced melanoma. N Engl J Med. 2013;369:122-133.

48. Le DT, Uram JN, Wang H, et al. PD-1 blockade in tumors with mismatch-repair deficiency. N Engl J Med. 2015;372(26):2509-2520.

49. Gandhi L, Balmanoukian A, Hui R, et al. Abstract CT105: MK-3475 (anti-PD-1 monoclonal antibody) for non-small cell lung cancer (NSCLC): antitumor activity and association with tumor PD-L1 expression. Cancer Res. 2014;74:CT105.

50. Marti AM, Martinez P, Navarro A, et al. Concordance of PD-L1 expression by different immunohistochemistry (IHC) definitions and in situ hybridization (ISH) in squamous cell carcinoma (SCC) of the lung. J Clin Oncol. 2014;32(Suppl 5):abstr 7569.

51. Mansfield AS, Roden AC, Peikert T, et al. B7-H1 expression in malignant pleural mesothelioma is associated with sarcomatoid histology and poor prognosis. J Thorac Oncol. 2014;9(7):1036-1040.

52. Bellmunt J, Mullane SA, Werner L, et al. Association of PD-L1 expression on tumor-infiltrating mononuclear cells and overall survival in patients with urothelial carcinoma. Ann Oncol. 2015;26(4):812-817.

53. Latchman YE, Liang SC, Yin W, et al. PD-L1-deficient mice show that PD-L1 on T cells, antigen-presenting cells, and host tissues negatively regulates T cells. Proc Natl Acad Sci US A. 2004;101(29): 10691-10696.

54. Deng L, Liang H, Burnette B, et al. Irradiation and anti-PD-L1 treatment synergistically promote antitumor immunity in mice. J Clin Invest. 2014;124(2):687-695.

55. Marco G, Rowan AJ, Stuart H, et al. Intratumor heterogeneity and branched evolution revealed by multiregion sequencing. $N$ Engl J Med. 2012;366:883-892.

56. Pardoll DM. The blockade of immune checkpoints in cancer immunotherapy. Nat Rev Cancer. 2012;12(4):252-264.

57. Zeng Z, Shi F, Zhou L, et al. Upregulation of circulating PD-L1/PD-1 is associated with poor post-cryoablation prognosis in patients with HBV-related hepatocellular carcinoma. PLos One. 2011;6(9):e23621.

58. Thompson RH, Dong H, Kwon ED. Implications of B7-H1 expression in clear cell carcinoma of the kidney for prognostication and therapy. Clin Cancer Res. 2007;13(2 Pt 2):709s-715s.

59. Hamanishi J, Mandai M, Iwasaki M, et al. Programmed cell death 1 ligand 1 and tumor-infiltrating CD8+ T lymphocytes are prognostic factors of human ovarian cancer. Proc Natl Acad Sci U S A. 2007;104(9):3360-3365.

60. Schalper KA, Velcheti V, Carvajal D, et al. In situ tumor PD-L1 mRNA expression is associated with increased TILs and better outcome in breast carcinomas. Clin Cancer Res. 2014;20(10):773-2782.

61. Lipson EJ, Vincent JG, Loyo M, et al. PD-L1 expression in the Merkel cell carcinoma microenvironment: association with inflammation, Merkel cell polyomavirus and overall survival. Cancer Immunol Res. 2013; 1(1):54-63.

62. Chen YB, Mu CY, Huang JA. Clinical significance of programmed death-1 ligand-1 expression in patients with non-small cell lung cancer: a 5-year-follow-up study. Tumori. 2012;98:751-755.

63. Hino R, Kabashima K, Kato Y, et al. Tumor cell expression of programmed cell death-1 ligand 1 is a prognostic factor for malignant melanoma. Cancer. 2010;116(7):1757-1766.

64. Taube JM, Anders RA, Young GD, et al. Colocalization of inflammatory response with B7-h1 expression in human melanocytic lesions supports an adaptive resistance mechanism of immune escape. Sci Transl Med. 2012;4(127):127-137.

65. Karim R, Jordanova ES, Piersma SJ, et al. Tumor-expressed B7-H1 and $\mathrm{B} 7-\mathrm{DC}$ in relation to $\mathrm{PD}-1+\mathrm{T}$-cell infiltration and survival of patients with cervical carcinoma. Clin Cancer Res. 2009;15(20):6341-6347.

66. Thompson RH, Kuntz SM, Leibovich BC, et al. Tumor B7-H1 is associated with poor prognosis in renal cell carcinoma patients with long-term follow-up. Cancer Res. 2006;66(7):3381-3385.

67. Hamanishi J, Mandai M, Abiko K, et al. The comprehensive assessment of local immune status of ovarian cancer by the clustering of multiple immune factors. Clin Immunol. 2011;141(3):338-347.

68. Wang Y, Zhuang Q, Zhou S, Hu Z, Lan R. Costimulatory molecule B7-H1 on the immune escape of bladder cancer and its clinical significance. J Huazhong Univ Sci Technolog Med Sci. 2009;29(1):77-79. 
69. Cunha LL, Marcello MA, Morari EC, et al. Differentiated thyroid carcinomas may elude the immune system by B7H1 upregulation. Endocr Relat Cancer. 2013;20(1):103-110.

70. D'Angelo SP, Shoushtari AN, Agaram NP, et al. Prevalence of tumorinfiltrating lymphocytes and PD-L1 expression in the soft tissue sarcoma microenvironment. Human Pathol. 2015;46(3):357-365.

71. Ukpo OC, Thorstad WL, Lewis JS. B7-H1 expression model for immune evasion in human papillomavirus-related oropharyngeal squamous cell carcinoma. Head Neck Pathol. 2013;7:113-121.

72. Ye Y, Zhou L, Xie X, Jiang G, Xie H, Zheng S. Interaction of B7-H1 on intrahepatic cholangiocarcinoma cells with PD-1 on tumor-infiltrating T cells as a mechanism of immune evasion. J Surg Oncol. 2009;100(6): 500-504.

73. Liu J, Hamrouni A, Wolowiec D, et al. Plasma cells from multiple myeloma patients express B7-H1 (PD-L1) and increase expression after stimulation with IFN-\{gamma $\}$ and TLR ligands via a MyD88-, TRAF6-, and MEK-dependent pathway. Blood. 2007;110(1):296-304.

74. Salih HR, Wintterle S, Krusch M, et al. The role of leukemia-derived B7-H1 (PD-L1) in tumor-T-cell interactions in humans. Exp Hematol. 2006;34(7):888-894.

75. Gao Q, Wang XY, Qiu SJ, et al. Overexpression of PD-L1 significantly associates with tumor aggressiveness and postoperative recurrence in human hepatocellular carcinoma. Clin Cancer Res. 2009;15(3): 971-979.

76. Shi F, Shi M, Zeng Z, et al. PD-1 and PD-L1 upregulation promotes CD8(+) T-cell apoptosis and postoperative recurrence in hepatocellular carcinoma patients. Int J Cancer. 2011;128(4):887-896.

77. Thompson RH, Gillett MD, Cheville JC, et al. Costimulatory molecule B7-H1 in primary and metastatic clear cell renal cell carcinoma. Cancer. 2005;104(10):2084-2091.

78. Boorjian SA, Sheinin Y, Crispen PL, et al. T-cell coregulatory molecule expression in urothelial cell carcinoma: clinicopathologic correlations and association with survival. Clin Cancer Res. 2008;14(15):4800-4808.

79. Inman BA, Sebo TJ, Frigola X, et al. PD-L1 (B7-H1) expression by urothelial carcinoma of the bladder and BCG-induced granulomata: associations with localized stage progression. Cancer. 2007;109(8): 1499-1505.

80. Xylinas E, Robinson BD, Kluth LA, et al. Association of T-cell coregulatory protein expression with clinical outcomes following radical cystectomy for urothelial carcinoma of the bladder. Eur J Surg Oncol. 2013;40(1):121-127.

81. Konishi J, Yamazaki K, Azuma M, Kinoshita I, Dosaka-Akita H, Nishimura M. B7-H1 expression on non-small cell lung cancer cells and its relationship with tumor-infiltrating lymphocytes and their PD-1 expression. Clin Cancer Res. 2004;10:5094-5100.
82. Wintterle S, Schreiner B, Mitsdoerffer M, et al. Expression of the B7-related molecule B7-H1 by glioma cells: a potential mechanism of immune paralysis. Cancer Res. 2003;63(21):7462-7467.

83. Jiang D, Xu YY, Li F, Xu B, Zhang XG. The role of B7-H1 in gastric carcinoma: clinical significance and related mechanism. Med Oncol. 2014;31(11):268.

84. Wang BJ, Bao JJ, Wang JZ, et al. Immunostaining of PD-1/PD-Ls in liver tissues of patients with hepatitis and hepatocellular carcinoma. World J Gastroenterol. 2011;17(28):3322-3329.

85. Zhao LW, Li C, Zhang RI, et al. B7-H1 and B7-H4 expression in colorectal carcinoma: correlation with tumor FOXP3+ regulatory T-cell infiltration. Acta Histochem. 2014;116(7):1163-1168.

86. Curiel TJ, Wei S, Dong H, et al. Blockade of B7-H1 improves myeloid dendritic cell-mediated antitumor immunity. Nat Med. 2003;9(5): $562-567$.

87. Ghebeh H, Mohammed S, Al-Omair A, et al. The B7-H1 (PD-L1) $\mathrm{T}$ lymphocyte-inhibitory molecule is expressed in breast cancer patients with infiltrating ductal carcinoma: correlation with important high-risk prognostic factors. Neoplasia. 2006;8(3):190-198.

88. Routh JC, Ashley RA, Sebo TJ, et al. B7-H1 expression in Wilms tumor: correlation with tumor biology and disease recurrence. J Urol. 2008;179(5):1954-1959.

89. Chen X, Liu S, Wang L, Zhang W, Ji Y, Ma X. Clinical significance of B7-H1 (PD-L1) expression in human acute leukemia. Cancer Biol Ther. 2008;7(5):622-627.

90. Zhang J, Fang W, Qin T, et al. Co-expression of PD-1 and PD-L1 predicts poor outcome in nasopharyngeal carcinoma. Med Oncol. 2015; 32(3):86.

91. Westin JR, Chu F, Zhang M, et al. Safety and activity of PD1 blockade by pidilizumab in combination with rituximab in patients with relapsed follicular lymphoma: a single group, open-label, Phase 2 trial. Lancet Oncol. 2014;15(1):69-77.

92. Armand P, Nagler A, Weller EA, et al. Disabling immune tolerance by programmed death-1 blockade with pidilizumab after autologous hematopoietic stem-cell transplantation for diffuse large B-cell lymphoma: results of an international Phase II trial. JClin Oncol. 2013;31(33): 4199-4206.

93. Hamid O, Robert C, Daud A, et al. Safety and tumor responses with lambrolizumab (anti-PD-1) in melanoma. N Engl J Med. 2013;369: 134-144.
OncoTargets and Therapy

\section{Publish your work in this journal}

OncoTargets and Therapy is an international, peer-reviewed, open access journal focusing on the pathological basis of all cancers, potential targets for therapy and treatment protocols employed to improve the management of cancer patients. The journal also focuses on the impact of management programs and new therapeutic agents and protocols on

\section{Dovepress}

patient perspectives such as quality of life, adherence and satisfaction. The manuscript management system is completely online and includes a very quick and fair peer-review system, which is all easy to use. Visit http://www.dovepress.com/testimonials.php to read real quotes from published authors. 